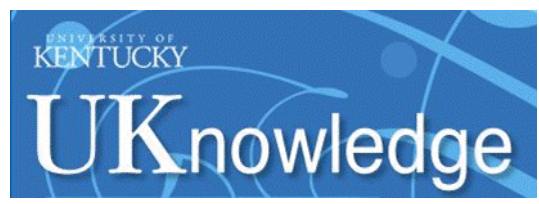

University of Kentucky

UKnowledge

\title{
The New Small Business Bankruptcy Game: Strategies for Creditors Under the Small Business Reorganization Act
}

Christopher G. Bradley

University of Kentucky College of Law, cgbradley@uky.edu

Follow this and additional works at: https://uknowledge.uky.edu/law_facpub

Part of the Bankruptcy Law Commons

Right click to open a feedback form in a new tab to let us know how this document benefits you.

\section{Repository Citation}

Bradley, Christopher G., "The New Small Business Bankruptcy Game: Strategies for Creditors Under the Small Business Reorganization Act" (2020). Law Faculty Scholarly Articles. 649.

https://uknowledge.uky.edu/law_facpub/649

This Article is brought to you for free and open access by the Law Faculty Publications at UKnowledge. It has been accepted for inclusion in Law Faculty Scholarly Articles by an authorized administrator of UKnowledge. For more information, please contact UKnowledge@lsv.uky.edu. 


\section{The New Small Business Bankruptcy Game: Strategies for Creditors Under the Small Business Reorganization Act}

\section{Notes/Citation Information}

Christopher G. Bradley, The New Small Business Bankruptcy Game: Strategies for Creditors Under the Small Business Reorganization Act, 28 Am. Bankr. Inst. L. Rev. 47 (2020). 
THE NEW SMALL BUSINESS BANKRUPTCY GAME: STRATEGIES FOR CREDITORS UNDER THE SMALL BUSINESS REORGANIZATION ACT

\author{
CHRISTOPHER G. BRADLEY*
}

TABLE OF CONTENTS

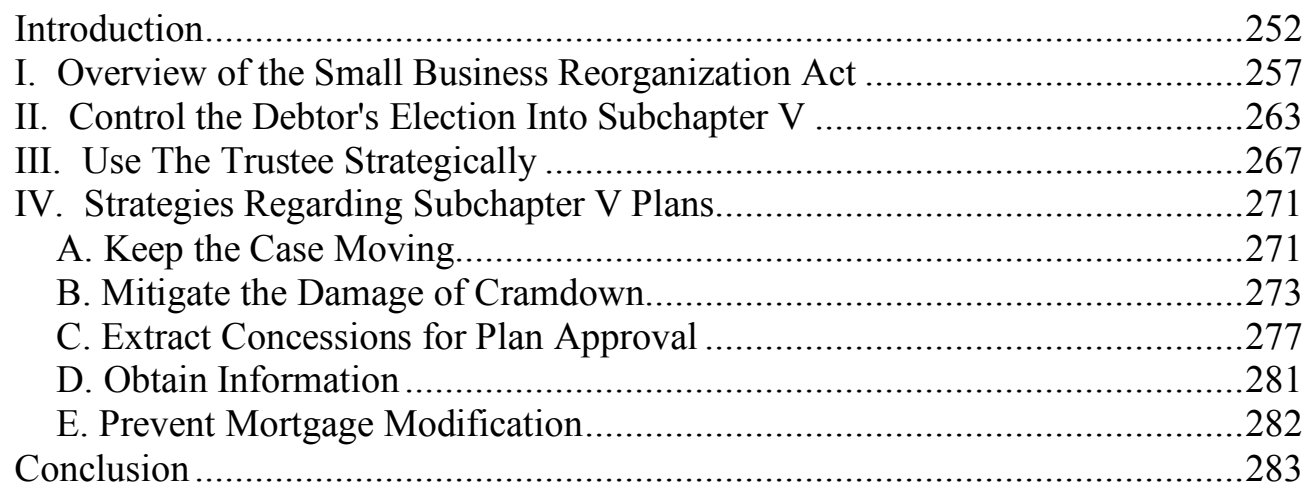

\footnotetext{
* Wyatt, Tarrant \& Combs Associate Professor of Law, University of Kentucky, J. David Rosenberg College of Law. I am grateful to the editors of the American Bankruptcy Institute Law Review for their help in the publication of this Article, and to Hon. Paul Bonapfel, Ralph Brubaker, Kara Bruce, Christopher Frost, Brook Gotberg, Melissa Jacoby, Ted Janger, Allan NewDelman, and Hon. Tracey Wise, for their helpful comments and critiques. I am also grateful to Lynn M. LoPucki and Christopher R. Mirick, whom I will be joining as co-author for the seventh edition of their authoritative book, Strategies for Creditors in Bankruptcy Proceedings (forthcoming 2020). I am grateful to my co-authors for helping me begin to frame and elaborate some potential strategic dimensions of this important new law. That said, I alone take responsibility for the statements in this Article.
} 


\section{INTRODUCTION}

In late 2019, Congress passed and the President signed an important new law, the Small Business Reorganization Act (the "Act"). ${ }^{1}$ The Act, which went into effect on February 19, 2020, provides a significant subset of debtors, both individual and corporate, with powerful options under a new "subchapter V" of chapter 11 of the Bankruptcy Code. Bankruptcies under the new subchapter will be governed by a set of rules that bear more resemblance to chapter 12 or chapter 13 than to traditional chapter 11. Basically, subchapter $\mathrm{V}$ requires debtors to pay available net income to creditors over a few years, but it permits current owners to retain the equity interest in the business, even if no creditors agree to the plan.

The Act's timing is remarkable. The COVID-19 pandemic has led to a dramatic drop in the demand for the goods and services of many small businesses. Thus, only months after its passage, this new subchapter of chapter 11 may be called upon to provide significant aid to the vast numbers of small businesses endangered by the dramatic events of $2020 .^{2}$ Indeed, the Act has already been amended, under the pandemic-related "CARES" Act, so that subchapter V relief is available to many more debtors. ${ }^{3}$

Creditors will have to develop a new playbook for subchapter V. The contents of this playbook depend greatly on how debtors use subchapter $\mathrm{V}$, how trustees play their role under it, and how judges interpret it. This Article presents a preliminary strategic analysis of the Act from the perspective of creditors that will be affected by it. Experience will be the crucible in which creditors will have to refine these strategies. The choices of creditors and other players of the small business

\footnotetext{
${ }^{1}$ Small Business Reorganization Act of 2019, Pub. L. No. 116-54, 133 Stat. 1079 (codified at 11 U.S.C. $\S \S 1181-1195$ and scattered sections of 11 U.S.C. and 28 U.S.C. (2019)) [hereinafter the Act]. There are already several excellent analyses of the young Act. See Ralph Brubaker, The Small Business Reorganization Act of 2019, 38 BANKR. L. LETTER, No. 10, Oct. 2019 at 1-4; Paul W. Bonapfel, A Guide to the Small Business Reorganization Act of 2019, 93 AM. BANKR. L.J. 571 (2019); U.S. DEP'T OF JUSTICE, 3 United States Trustee Program Policy and Practices Manual: Chapter 11 Case ADMINISTRATION (Feb. 2020), https://www.justice.gov/ust/file/ volume_3_chapter_11_case_administration.pdf/download [hereinafter U.S. TRUSTEE MANUAL]. Among the many valuable aspects of Brubaker's article is his summary of the Act's predecessors and genesis. See Brubaker, supra. For further background on the motivations of various of its provisions, see Commission to Study the Reform of Chapter 11, 2012-2014 Final Report and Recommendations, AM. BANKR. INST. (2014), http://commission.abi.org/full-report [hereinafter ABI Commission Report]; National Bankruptcy Conference, A Proposal for Amending Chapter 12 to Accommodate Small Business Enterprises Seeking to Reorganize (Jan. 3, 2010), http://nbconf.org/wp-content/uploads/2015/07/NBC-Small-Business-Rept-Dec-17 -2009.pdf; H.R. REP. NO. 116-171, at 2 (2019), https://www.govinfo.gov/content/pkg/CRPT-116hrpt171/ pdf/CRPT-116hrpt 171.pdf.

${ }^{2}$ See, e.g., Amy Haimerl, When Does a Small Business File for Bankruptcy? And 8 More Questions, N.Y. TIMES (June 18, 2020), https://www.nytimes.com/article/small-business-bankruptcy-coronavirus.html; Christopher G. Bradley, Feds Give a Bankruptcy Lifeline to Small Businesses Hurt in Pandemic, LEXINGTON HERALD-LEADER (Apr. 17, 2020), www.kentucky.com/opinion/op-ed/article241969391.html.

${ }^{3}$ See infra note 56 and accompanying text.
} 
bankruptcy game will over time determine subchapter V's meaning, as it goes from being a law-in-books to a lived reality of law-in-action. ${ }^{4}$

The strategic perspective of this Article is grounded in this law-in-action tradition; its goal is to uncover ways in which participants in the bankruptcy system can position themselves to benefit under its rules. The rules are established by the panoply of laws that govern creditors and debtors in or on the cusp of financial distress. Creditors strategically strive against the debtor and against each other to obtain as much of the debtor's remaining present and potential future value as possible. This process begins well in advance of any actual court proceeding or filing, and continues until all issues are finally resolved. It involves considering opportunities to affect each discrete phase of a business relationship or a bankruptcy case, and implicates different types of lawyering, from structuring transactions to monitoring relationships to negotiations and litigation. Each strategy also has to be weighed in light of industry norms and in the context of each business relationship.

The strategic perspective is premised on the observation "[t]here are many ways to go with a case, some are better than others, and it requires a profound understanding of both the case and the system to choose wisely among them." ${ }^{5}$ This Article illuminates ways in which creditors can seek to "choose wisely" among various options for developing the facts of their cases and shaping the law that will determine the outcome of their case. While bankruptcy and commercial law scholarship often implicitly or explicitly includes astute analysis of strategies, ${ }^{6}$ usually the strategic observations or predictions are incidental to the work's other goals. ${ }^{7}$ This Article foregrounds strategic considerations with the modest aim of achieving a preliminary account of the effects of the Act on creditors' options with respect to debtors in financial distress. This approach will, I hope, appeal both to practitioners and to scholars of bankruptcy.

\footnotetext{
${ }^{4}$ See generally Roscoe Pound, Law in Books and Law in Action, 44 AM. L. REV. 12 (1910); see also Melissa B. Jacoby, Ripple or Revolution? The Indeterminacy of Statutory Bankruptcy Reform, 79 AM. BANKR. L.J. 169, 177 (2005) (presenting similar observations regarding the 2005 bankruptcy reforms).

5 LYNN M. LOPUCKI \& CHRISTOPHER R. Mirick, STRATEgIES FOR CREDITORS IN BANKRUPTCY PROCEEDINGS xvii (6th ed. 2015). The best explanation of what "legal systems" and "strategic analysis" mean is Lynn M. LoPucki, Legal Culture, Legal Strategy, and the Law in Lawyers' Heads, 90 Nw. U. L. REV. 1498 (1996). See also Lynn M. LoPucki, The Death of Liability, 106 YALE L.J. 1, 6 (1996) ("Strategies are changes in conduct by a system participant made with the intention to improve the participant's treatment by the system. System designers, such as legislators, judges, and influential commentators, intend to foster some strategic action by system participants .... But participants in a system often devise strategies not contemplated, or at least not intended, by the system designers.").

${ }^{6}$ See, e.g., Pamela Foohey, Bankrupting the Faith, 78 Mo. L. REV. 719, 751 (2013) (describing uses of chapter 11 by religious organizations); Melissa B. Jacoby \& Edward J. Janger, Ice Cube Bonds: Allocating the Price of Process in Chapter 11 Bankruptcy, 123 YALE L.J. 862, 873-874 (2014) (describing common use (in their view over-use) of strategic arguments regarding the urgency of the need for relief by debtors); Jared A. Ellias \& Robert J. Stark, Bankruptcy Hardball, 108 CAL. L. REV. 745 (2020) (describing modern debtor "hardball" tactics).

${ }^{7}$ For example, to present theoretical, empirical, or historical research, often in support of a normative argument.
} 
This Article recapitulates my understanding of the Act's goals but does not delve deeply into the motivations for the Act or the Act's success at accomplishing those goals. All laws involve tradeoffs, and further study will be needed to analyze whether the costs of this law are worth its benefits. I will also leave to others to propose changes to the law, including in response to the strategies offered in this Article. In other words, this strategic account should not be mistaken for a normative analysis of the Act.

This Article considers creditors' preferences and possibilities because among thinkers about bankruptcy, whether professors or practitioners, the debtor's perspective is the one most commonly discussed. ${ }^{8}$ Creditors' perspectives have been less well-explored. This is certainly true of commentary concerning the new Act, most of which has emphasized the options created for debtors. ${ }^{9}$ This Article considers the debtor's likely choices only in order to explore the options those choices might open up, or foreclose, for creditors.

Creditors are not created equal. Strategies will only be useful to creditors with claims substantial enough to justify the investment of time and money that executing a strategy would entail. And most strategies do not benefit creditors as a whole. The game is multilateral, not simply creditor vs. debtor. Well-positioned creditors will extract whatever strategic gains they can at the expense of the debtor and of less privileged creditors.

Secured creditors have more incentive and leverage to act strategically, including under the Act. Sophisticated financial creditors will likely be able to take care of themselves and their interests under the Act. Even where their interests are adversely affected, large institutional creditors have the ability to price in bankruptcy risk in a way that other creditors may not. It may be unsecured creditors such as trade and tort creditors whose interests are most affected by subchapter V, yet who are least positioned to protect themselves against such effects. For many supporters of the Act, limiting the perceived overreaching of certain creditors-in particular, undersecured creditors with both significant secured claims and large unsecured deficiency claims - has been articulated as a goal of the Act. This Article suggests the Act likely will not accomplish that goal.

Most unsecured creditors have little incentive to act energetically in bankruptcy proceedings. They are unlikely to be paid enough to make it worth the effort. Our

\footnotetext{
8 This is not to say that chapter 11 itself has been consistently dominated by a pro-debtor point of view. Indeed, the current Bankruptcy Code, as with its predecessor Bankruptcy Act, has seen numerous shifts of power and attention. See, e.g., DAVID A. SKEEL, DEBT's DOMINION: A History OF BANKRUPTCY LAW IN AMERICA (2001) (providing a historical overview of the prior act and the origins of the modern code); Melissa B. Jacoby, Fast, Cheap, and Creditor-Controlled: Is Corporate Reorganization Failing?, 54 BuFF. L. REV. 401, 429-431 (2006) (explaining pro-creditor shift in chapter 11); David A. Skeel Jr., Creditors' Ball: The "New" New Corporate Governance in Chapter 11, 152 U. PA. L. REV. 917, 920-933 (2003) (same).

${ }_{9}$ There are exceptions. See, e.g., Brubaker, supra note 1, at 14-15 (discussing one way under subchapter $\mathrm{V}$ in which a secured creditor might be able to "extract more-than-full payment of the secured portion of its claim" or other concessions from the debtor).
} 
bankruptcy law allocates much more power to debtors and to secured claimants. This Article suggests that the Act further erodes the position of most unsecured creditors. Their expected recoveries will remain too low to justify anything other than a relatively passive attitude toward the bankruptcy proceeding, and the Act lowers the protections for passive creditors.

Part I provides an overview of the major features of the Act. ${ }^{10}$ It explains how a subchapter $\mathrm{V}$ case is initiated and discusses the major differences between subchapter V and standard bankruptcy law. Subchapter V dramatically eases the requirements for confirmation of nonconsensual chapter 11 plans; strongly encourages consensual plans through several new incentives; lowers the debtor's disclosure obligations while removing in most cases the possibility of an official committee of creditors; and requires the appointment of a trustee with a significantly different role than under any other part of the Bankruptcy Code. The Act also permits modification of loans secured by a mortgage on a debtor's primary residence, which the Bankruptcy Code otherwise disallows.

Part II sketches strategic considerations relating to eligibility and election into subchapter V. Subchapter V is voluntary and only open to qualified debtors. This Part explores how creditors may influence or control a debtor's choices or options. Strategies including making agreements with debtors concerning the election; using financial maneuvers to work around the debt limits that control entry into subchapter V; and challenging the debtor's eligibility for relief under the subchapter.

Part III explores the strategic implications of the addition of the subchapter V trustee and the elimination of the creditors' committee. ${ }^{11}$ Subchapter V disturbingly lacks reliable mechanisms to ensure that the trustee take creditors' interests seriously. This Part suggests strategies for creditors to explore ways to make their voices heard in light of the Act's institutional re-alignment, which disfavors them. Strategies range from cultivating and working closely with the trustee, to seeking to minimize the role of the trustee, to opposing and seeking removal of the trustee.

Part IV discusses plans of reorganization under subchapter $\mathrm{V}$, and how creditors can strategically seek to shape the outcome of the plan process.

First, creditors should resist delay in the plan process. Debtors often seek to extend cases and delay plan confirmation, but lengthy cases are generally costly and prejudicial to creditors' interests. Subchapter V gives debtors exclusive control of the plan proposal process and has no deadline for plan confirmation, so delay is a

\footnotetext{
${ }^{10}$ For a more detailed treatment, see supra note 1 (collecting sources). These writings help place the Act in context of existing practice under not just chapter 11 but also chapters 12 and 13-which the new law in some ways resembles more than it does standard chapter 11. This Article does not discuss the provisions of the Act that are applicable in all bankruptcy proceedings, such as the amendments to avoidable preference law. See generally Brubaker, supra note 1, at 19-20 (describing these amendments).

11 As in many other aspects of the law, a court may "order otherwise," here "for cause." See 11 U.S.C. $\S 1102(a)(3)$ (2018). I generally omit this possibility, but where I suspect courts may be willing to order otherwise on a regular basis, I have so noted.
} 
major danger to creditors in subchapter V proceedings. Still, creditors can make use of the statutorily prescribed timeline and required disclosures to hold the debtor's feet to the fire. This may be particularly effective if creditors lay groundwork early in the process and strategically make their case to the trustee and court.

Second, creditors should mitigate the damage of subchapter V's "cramdown" provisions. If creditors do not consent to a plan, Subchapter $\mathrm{V}$ requires that debtors commit their net income to creditors for a period of three to five years. The income calculation will be easily manipulated by debtors, to the disadvantage of general unsecured creditors in particular. Creditors can seek to mitigate this harm by trying to avoid holding a general unsecured claim at the petition date. In addition, eligible creditors should consider taking the election offered by section 1111(b) of the Code, which may improve their status and provide them with leverage.

Third, creditors whose votes are necessary for consensual plan confirmation should extract concessions from the debtor in exchange for their vote. The Act places a premium on debtors' plans being consensual rather than "cramdown." For those privileged creditors whose votes are needed for consensual confirmation, in particular creditors holding both a secured claim and a large unsecured deficiency claim, this will be a major point of leverage. ${ }^{12}$

Fourth, creditors should obtain information from and about debtors, in order to inform plan-related strategic decisions. Although subchapter $\mathrm{V}$ requires less disclosure from debtors and lacks some creditor-protective structures of standard bankruptcy law, motivated creditors can take advantages of opportunities to obtain information, including the meeting of creditors and required status conference early in the case, the disclosures and filings of the debtor, and discovery under Federal Rule of Bankruptcy Procedure 2004. These are unlikely to overcome creditors' informational disadvantages under subchapter $\mathrm{V}$ but should be considered.

Fifth, creditors should ensure their home loans cannot be modified in bankruptcy. The Act gives debtors a new opportunity to reduce secured claims on debtors' homes. Creditors should consider how to structure loans strategically in order to ensure that they cannot be disadvantageously modified by debtors in bankruptcy.

Part V concludes. It predicts that powerful secured creditors will not lose much ground under subchapter $\mathrm{V}$, but that general unsecured creditors are likely to see their interests damaged by subchapter V. Several of the strategic tools presented in this Article are available even to disfavored creditors, if they have the inclination to play the small business bankruptcy game. But in the end, unsecured creditors are

\footnotetext{
12 Notably, while a key impetus for subchapter V was, according to its supporters, to dampen the influence of secured creditors with large deficiency claims, such creditors are likely to retain outsized influence. See infra notes 18, 21, 111-116, 124 and accompanying text. Subchapter V's primary effect is probably to redistribute power from the other creditors - junior and/or unsecured creditors - to the debtor.
} 
poorly positioned to defend against the erosion of their interests and usually have little financial incentive to do so.

\section{OVERVIEW OF THE SMALL BUSINESS REORGANIZATION ACT}

Though the Act is only several months old, it has garnered several excellent descriptive treatments, and the reader interested in the finer points of the Act should consult those works. ${ }^{13}$ This Part provides an overview so that a reader otherwise unacquainted with the Act to understand the strategic discussions that follow.

The Act provides small business debtors, including entities and individuals, with a voluntary alternative to the law otherwise governing small business bankruptcies. Notably, the prior small business provisions will remain in force and, at least in theory, apply as the default provisions for small business debtors that do not "elect" to proceed under subchapter V. ${ }^{14}$ In this Article, for clarity, I refer to general business bankruptcy law as "standard chapter 11," non-subchapter V small business law as the "standard small business provisions," and the new law as "subchapter V" or "the Act."

The standard small business provisions have never been widely used by debtors - even by those that meet the eligibility requirements and are supposed to file under them. ${ }^{15}$ Businesses avoid filing under the standard small business provisions for a number of reasons. ${ }^{16}$ The provisions establish firm deadlines for plan confirmation and impose additional disclosure requirements on small business debtors. ${ }^{17}$ They streamline some requirements but leave many features of standard chapter 11 in place. Three aspects of standard chapter 11, which remain applicable in standard small business cases, are thought to be particularly detrimental to small business reorganizations.

First, there is the "absolute priority rule," which provides, in essence, that a business owner cannot retain an ownership interest without paying all creditors in

\footnotetext{
13 See supra note 1.

${ }^{14}$ See Bonapfel, supra note 1, at 575-76.

15 This problem is well recognized in the literature. See, e.g., Brubaker, supra note 1, at 6; ABI Commission Report, supra note 1, at 289-90 ("[T] he failure to self-identify as a small business debtor may be an oversight, it may be the result of the somewhat complicated definition of 'small business debtor' . . or it may be a desire to avoid the obligations and deadlines imposed on small business debtors under current law."); Bob Lawless, The Disappearing Small Businesses (Designation) in Bankruptcy, CREDIT SLIPS (Apr. 30, 2010), https://www.creditslips.org/creditslips/2010/04/the-disappearing-small-businesses-designation-inbankruptcy.html (noting only $36.8 \%$ of potentially eligible chapter 11 cases in 2007 identified as small business debtors); Steve Sather, When Is a Small Business Debtor Not a Small Business Debtor? (Apr. 6, 2009), http://stevesathersbankruptcynews.blogspot.com/2009/04/when-is-small-business-debtor-not-small. html.

${ }^{16}$ For an overview of the history and rationale of various small business bankruptcy laws, see Brubaker, supra note 1, at 1-4; ABI Commission Report, supra note 1, at 276-81.

17 On the standard small business provisions, see Robert M. Lawless, Small Business and the 2005 Bankruptcy Law: Should Mom and Apple Pie Be Worried, 31 S. ILL. U. L.J. 585 (2007).
} 
full or receiving the consent of each class of creditors. ${ }^{18}$ Often, small businesses have a primary creditor that has financed much of the debtor's operations and that attains a senior secured position, but that by the time of the bankruptcy has collateral worth far less than the amount of its claim. Such a creditor has not only a security interest in substantially all of the debtor's assets but also a substantial unsecured deficiency claim, often larger than all other unsecured claims combined. This allows it to prevent the class of general unsecured creditors from accepting a plan. Thus, even if a business has a bright future, a creditor with a large unsecured claim such as a large deficiency claim can essentially determine if the owner can retain an interest in the reorganized entity.

This essentially gives such a creditor veto power over reorganization. Unlike most larger enterprises, small-sized and medium-sized businesses are not usually managed by outside professionals but by the owners themselves. Owners are reluctant to work to "save" the business if it means relinquishing their ownership interests. For this reason, when a crucial creditor will not agree to a reorganization (in or out of court), owners often avoid filing bankruptcy, letting the business stagger along, hoping against hope for a revival, generally until it collapses and liquidates. $^{19}$

Second, in order for a plan to be confirmed, a class of creditors whose interests are impaired under the plan has to consent to it. ${ }^{20}$ This requirement gives powerful creditors control over the confirmation. Here, too, a senior secured creditor with a large deficiency claim often wields veto power. These veto-holding creditors are thought to have outsized sway over the outcome of cases, often to the disadvantage of debtors and less powerful creditors. ${ }^{21}$

Third, the standard requirements of drafting and promulgating a full dress disclosure statement and going through the full plan confirmation process are thought to be burdensome and unnecessary in many small business cases. ${ }^{22}$ Small

\footnotetext{
${ }^{18}$ This is the meaning given to the requirement that a plan be "fair and equitable" under normal chapter 11 rules. See 11 U.S.C. $\S 1129(b)(2)(2018)$.

${ }^{19}$ Brubaker, supra note 1, at 2, 11; ABI Commission Report, supra note 1, at 299.

2011 U.S.C. $\$ 1129(\mathrm{a})(10)$.

${ }^{21}$ See Brubaker, supra note 1, at 7, 12-13, 16 (describing this issue). One important but difficult-to-predict aspect of the Act is whether it will change the common practice of a secured creditor, with a lien on substantially all of the debtor's assets, funding a bankruptcy case intended primarily to sell the debtor's assets, often with the creditor acting as "stalking-horse" bidder. Such cases may now turn more often to reorganization plans rather than sales under section 363, which have served as the main events of many bankruptcies. A shift to plans seems to be an intended effect of the drafters of the Act. Cf. ABI Commission Report, supra note 1, at 298-302. It remains to be seen how much this change (assuming it occurs) will benefit the main body of creditors, in the end. Most creditors have reason to doubt that they will be better off.

22 See, e.g., ABI Commission Report, supra note 1, at 58-59, 59 n.221, $84 \mathrm{n} .318$ (discussing the relatively modest and quarterly fees owed to the U.S. Trustee and the ability of impaired creditors to vote on a plan); Grassley et al., The Small Business Reorganization Act, https://www.grassley.senate.gov/sites/default/files/ documents/Bankruptcy\%2C\%2004-09-19\%2C\%20Small\%20Business\%20Reorganization\%20Act\%20Fact \%20Sheet.pdf (describing the Act as "[r]educing [u]nnecessary [p]rocedural [b]urdens and [c]osts," in part by eliminating the disclosure statement requirement).
} 
business cases often have a low margin for error, and additional administrative fees can turn a case from potential success to certain failure. While the standard small business provisions simplify the plan process in some ways, ${ }^{23}$ they also impose strict and short timelines for reorganization plans,${ }^{24}$ which add expense and urgency to the process and make it less desirable.

The Act seeks to succeed where the standard provisions have failed. First and foremost, subchapter $\mathrm{V}$ dispenses with the absolute priority rule and the requirement that a plan garner the consent of an impaired class of creditors. ${ }^{25}$ Subchapter V permits the existing owners of an entity to maintain their control and their ownership. In order to confirm a plan over creditors' objections, the debtor simply needs to estimate its "disposable income" for a period of three to five years ${ }^{26}$ and pay that amount to creditors. ${ }^{27}$ These plan payments will be required to cover the claims of secured, ${ }^{28}$ administrative, ${ }^{29}$ and other priority claims ${ }^{30}$ in full, with any remainder going to general unsecured claims. There is no requirement that a plan pay anything to general unsecured creditors. And remarkably, if the debtor's disposable income proves to be higher than estimated, there is no requirement that the additional profit be shared with creditors.

In addition, the Act also permits subchapter $\mathrm{V}$ debtors to dispense with the disclosure statement and streamlines the plan process. The plan has to provide a light set of disclosures regarding the history of the debtor's operations, a liquidation analysis, and projections regarding the debtor's ability to fund the plan. ${ }^{31}$ Unlike the standard provisions, subchapter $\mathrm{V}$ does not require that "adequate information" be provided, ${ }^{32}$ although presumably the courts will develop some minimum standards for disclosures.

As with the standard small business provisions, subchapter $\mathrm{V}$ cases face an accelerated timetable: The subchapter $\mathrm{V}$ debtor has to appear before the court at a status conference within sixty days and propose a plan within ninety days of the petition date. ${ }^{33}$ But unlike the standard small business provisions, ${ }^{34}$ there is no hard-

\footnotetext{
${ }^{23}$ Lawless, supra note 15 , at $608-11$.

2411 U.S.C. $\$ 1121(\mathrm{e})$

25 See generally 11 U.S.C.A. $\$ 1191$ (West 2019) (permitting a court to confirm a plan only if the requirements of section 1129 (a) are met).

${ }^{26}$ While five years is the maximum time to require disposable income and for the general discharge to be ordered, plans may stretch longer than this time, for instance to pay long-term secured debts such as mortgages or payments to undersecured creditors that have taken the election. See, e.g., 11 U.S.C.A. § 1192 (implying that plan length can exceed the initial three- to five-year period). On the 1111(b) election, see infra notes 111-116, and accompanying text.

${ }_{27}$ See 11 U.S.C.A. $\$ 1191(\mathrm{~b})-(\mathrm{d})$.

2811 U.S.C. $\$ 1129(\mathrm{~b})(2)(\mathrm{A})(\mathrm{i})$.

${ }^{29}$ Brubaker, supra note 1, at 17; 11 U.S.C.A. $\$ 1191(\mathrm{e})$.

3011 U.S.C. $\$ 1129(\mathrm{a})(9)$.

3111 U.S.C.A. §1190(1); see also Donald L. Swanson, SBRA: Frequently Asked Questions and Some Answers, 38 AM. BANKR. INST. J., Nov. 2019 at 8 (describing the required disclosures as "lite").

3211 U.S.C. $\$ 1125$ (2018).

3311 U.S.C.A. § 1188(a) (West 2019) ("Status conference."); id. § 1189(b) ("Filing of the plan.").
} 
and-fast requirement of when the confirmation of the plan must be accomplished. Once a debtor has filed a plan, it can be modified, and confirmation put off, for as long as the court will tolerate such delay. ${ }^{35}$ Under subchapter $\mathrm{V}$, there is no point at which any party other than the debtor can file a plan, ${ }^{36}$ and only the debtor can seek to modify the plan. ${ }^{37}$ These relaxed requirements further sweeten the deal that subchapter $\mathrm{V}$ presents.

Maintaining accountability over debtors and representing creditors' interests have been persistent problems in small-sized and medium-sized chapter 11 cases. Creditors' committees are hard to convene and expensive to fund in such cases. ${ }^{38}$ Creditors are reluctant to serve on committees because most simply do not have enough money at stake. ${ }^{39}$ But this is thought to leave the debtor-often allied with a powerful secured creditor - to act unfettered, while the interest of the body of creditors remains unrepresented at the negotiating table. ${ }^{40}$ Where a committee can be formed, its professional fees, charged against the bankruptcy estate, are substantial, again threatening to capsize cases with small margins.

For these reasons, under the standard small business provisions, an official committee of unsecured creditors is not convened. ${ }^{41}$ These provisions seek to compensate for the lack of a creditor's committee by imposing timelines and disclosure requirements (discussed above). But the burdens of the standard small business provisions are widely considered too onerous and are avoided by many debtors despite their being nominally mandatory.

Subchapter V takes a different tack. To fill the gap left by the lack of a creditors' committee, the new subchapter orders the Office of the United States Trustee to appoint a trustee for each subchapter V case. ${ }^{42}$ The body of creditors has no role in selecting the subchapter $\mathrm{V}$ trustee, unlike, for instance, chapter $7 .{ }^{43}$ Subchapter V trustees' duties are not well-specified, but at a minimum trustees are

\footnotetext{
${ }^{34}$ See 11 U.S.C. $\$ \S 1121(\mathrm{e})(3), 1129(\mathrm{e})$.

3511 U.S.C.A. § 1193(a) (West 2019).

${ }^{36}$ Id. $\S 1189$ (a).

${ }^{37} I d . \S 1193$.

${ }^{38}$ See ABI Commission Report, supra note 1, at 38-43, 291-92 (noting that small business creditors do not have large enough claims to "warrant the time and money to participate actively in these cases").

39 ABI Commission Report, supra note 1, at 39 ("An individual creditor will often engage in a cost-benefit analysis to decide whether to serve on the unsecured creditors' committee. . . Consequently, unsecured creditors may decide, particularly in smaller chapter 11 cases, that the economics do not favor service on a committee of unsecured creditors.").

${ }^{40}$ On the potential strategic usefulness of a creditor's committee, see, for example, LOPUCKI \& MIRICK, supra note 5, at 566-67.

${ }^{41}$ This was a slight change in the standard small business provisions, included in the Act. See Brubaker, supra note 1 , at 9 .

42 See 11 U.S.C.A. § 1183(a) (West 2019) (requiring the United States Trustee to "appoint one disinterested person to serve as trustee" if not appointed under 28 U.S.C. $\S 586(\mathrm{~b})$ and qualified under 11 U.S.C. $\S 322)$.

4311 U.S.C. § 702(b). See, e.g., LOPUCKI \& MIRICK, supra note 5, at 353-55 (discussing the strategic usefulness of electing a creditor-favorable trustee).
} 
supposed to help "facilitate the development of a consensual plan of reorganization." ${ }^{44}$ Notably, unless the court so orders, they do not take control of the debtor's property or "investigate the financial affairs of the debtor." 45 Trustees can take on more expansive roles if the court loses faith in the debtor's management. ${ }^{46}$ But in the normal course, owners-managers will remain in possession of the entity and its property, and the trustee will have few of the investigatory or caretaking roles of trustees under most other chapters of the Bankruptcy Code. ${ }^{47}$ Trustees seem likely to play the role of mediator. Also, courts will likely solicit their views on aspects of plan confirmation such as feasibility and the projection of disposable income. The U.S. Trustee currently appoints trustees on a case-by-case basis, and the trustees will bill on an hourly basis for their services. ${ }^{48}$

If the trustee succeeds in negotiating a consensual plan of reorganization, then the job is terminated when the plan is substantially consummated..$^{49}$ If the plan is not consensual, then the trustee remains in place to administer the plan payments. Consensual plans are also encouraged by two other features of the Act: (1) a debtor whose plan is confirmed consensually receives an immediate discharge instead of a discharge only at the end of plan payments, ${ }^{50}$ and (2) the post-petition property of a debtor that confirms a "cramdown" (nonconsensual) plan remains property of the estate, whereas with a consensual plan, the debtor retains such property outside of the estate. ${ }^{51}$

"Consensual" does not necessarily mean unanimous. Under subchapter V, only if a class of claims fails to approve is the plan rendered nonconsensual. ${ }^{52}$ Class approval requires the favorable vote of more than half of the number of creditors

\footnotetext{
4411 U.S.C.A. § 1183(b)(7). As Judge Bonapfel notes, "[n]o other trustee has this duty." Bonapfel, supra note 1 , at 583

4511 U.S.C.A. $\$ 1183(\mathrm{~b})(1)$; see also 11 U.S.C. $\S \S 704(\mathrm{a})(7), 1302(\mathrm{~b})(1)$. In this respect, the subchapter V trustee resembles chapter 12 trustees. See id. $\S 1202(b)(2)$.

4611 U.S.C.A. § 1183(b)(2), (5).

47 Trustees under chapter $7,11,12$, and 13 all have different roles. See, e.g., 11 U.S.C. $§ 704$ (chapter 7); id. § 1106 (chapter 11, non-subchapter V); id. § 1202 (chapter 12); id. § 1302 (chapter 13). The subchapter $\mathrm{V}$ trustee arguably has the most minimal, and least well-defined, role of any-with chapter 12 a close second.

48 See, e.g., Verified Statement of Subchapter V Trustee, In re Access Entm't, (Bankr. W.D. Ky. Feb. 26, 2020) (No. 3:20-bk-30643) (stating hourly rate of \$300); Verified Statement of Subchapter V Trustee, In re Tonto Basin Concrete, Inc., (Bankr. D. Ariz. Apr. 2, 2020) (No. 2:20-bk-03540-PS) (stating hourly rate of $\$ 550$ ). If debtors elect into subchapter V in large numbers, the U.S. Trustee may appoint standing trustees to serve in various districts. The billing model would likely shift to a percentage basis. See Bonapfel, supra note 1, at 588-89; U.S. TRUSTEE MANUAL, supra note 1, at 187, 197, 199-200, 202-03.

4911 U.S.C.A. § 1183(c)(1) (West 2019).

${ }^{50} I d . \S 1181(\mathrm{c})$.

${ }^{51} I d$. $\S 1186(\mathrm{a})$. This is not to say the property will be paid out to creditors - there's no provision in subchapter $\mathrm{V}$ for adjusting the plan payments to include any excess. The effects of this provision are complicated, but at a minimum would involve more court supervision throughout the time of the plan than most debtors might prefer.

${ }^{52}$ See id. § 1191(b).
} 
voting in a given class, and more than two-thirds in amount of the claims voting. ${ }^{53}$ Sometimes, no one creditor will be able to determine the outcome of the class vote, but often large individual creditors can cause their class to be nonconsenting. This voting requirement apparently applies to any class, secured or unsecured, and the denial of consent has the same effect on the debtor even if the class is paid in full over time, so long as it is "impaired" under the plan. ${ }^{54}$

Another plan requirement bears mentioning. The Act requires that unless creditors consent, the plan must "provide[] appropriate remedies, which may include the liquidation of nonexempt assets, to protect the holders of claims or interests in the event that the payments are not made. ${ }^{155}$ Presumably, this means that a plan could specify procedural mechanisms in the event of default in plan payments, or could award creditors security interests or similar rights to the debtor's assets in the event of a liquidation.

The Act only applies to statutorily defined "small businesses," and permits them to opt in to the subchapter V scheme. "Small business" is defined to mean debtors that have no more than $\$ 2.7$ million in liquidated, noncontingent debts (to be inflation adjusted); as a result of congressional action in response to the COVID-19 pandemic, however, debtors with up to $\$ 7.5$ million may elect into subchapter $\mathrm{V}$ through at least late March 2021. ${ }^{56}$ Some commentators have suggested that there may be efforts to raise the cap on a permanent basis.

Small businesses can include both entities and natural persons, provided that they are "engaged in commercial or business activities" and "not less than half" of their debt "arose from the commercial or business activities of the debtor." 57 Individuals, for whom standard chapter 11 is usually an ill fit at best, may be the most likely parties to elect into subchapter $\mathrm{V} .{ }^{58}$ The Act also broadens the availability of subchapter $\mathrm{V}$ for real-estate focused debtors. Unlike prior small business provisions, which excluded a wider range of real estate businesses, now it is only debtors which meet the specific definition of "single asset real estate" entities that are excluded from the "small business" provisions. ${ }^{59}$

Finally, the Act changes the law regarding modification of mortgages on a principal residence. In bankruptcy parlance, "modification" of a secured loan usually means cutting the secured debt down to the actually secured amount (i.e.,

\footnotetext{
${ }^{53} 11$ U.S.C. $\S 1126(\mathrm{c})$.

54 Brubaker, supra note 1 , at 14 . There are also some less-than-perfectly-clear provisions for administrative creditors that may under some circumstances give a single one of them the ability to transform a plan into a nonconsensual one. Brubaker, supra note 1, at 16-17.

5511 U.S.C.A. $\S 1191(\mathrm{c})(3)(\mathrm{B})$.

${ }^{56}$ Coronavirus Aid, Relief, and Economic Security Act, S. 3548, 116th Cong., 2d Sess. (2020) (enacted); 11 U.S.C. $\S 101(51 \mathrm{D})(\mathrm{A})$.

${ }^{57} \mathrm{Id}$.

58 See Brubaker, supra note 1, at 11-12, 15.

${ }^{59}$ As revised, only debtors whose business falls under the specific Bankruptcy Code definition of "single asset real estate" are excluded from eligibility for subchapter V. See Bonapfel, supra note 1, at 581; 11 U.S.C. $\S 101(51 \mathrm{~B}),(51 \mathrm{D})(\mathrm{A})$.
} 
the amount the collateral is worth); the creditor holds an unsecured "deficiency" claim for the remainder of the amount owed, but this would usually be paid off at some inconsequential, pennies-on-the-dollar rate and discharged. Then, as far as the amount still treated as secured, the debtor pays the reduced principal amount over a lengthy period of time with interest. ${ }^{60}$ Thus, a loan modified in bankruptcy is essentially a new loan, often at a lower principal amount and with what the court determines is a market rate of interest, imposed upon a creditor.

Under standard bankruptcy law, debtors cannot modify a mortgage loan secured by their principal residence. ${ }^{61}$ The Act relaxes this prohibition by providing that a subchapter $\mathrm{V}$ debtor can modify a non-purchase money loan secured by a principal residence, provided that the new value received from the lender for the mortgage lien was used primarily for business purposes. ${ }^{62}$

\section{CONTROL THE DEBTOR'S ELECTION INTO SUBCHAPTER V}

This Part discusses strategies relating to whether debtors elect to proceed under the new subchapter. This discussion begins with strategies to prevent the election, before turning briefly to strategies designed to make an election more likely, should creditors wish for that outcome.

Qualifying debtors have the option to elect into the subchapter V scheme. ${ }^{63} \mathrm{In}$ theory, if a qualifying debtor does not elect, then it should be subject to the standard small business rules, which are not elective for debtors that fall within the definition. As mentioned, these rules impose quite strict guidelines, particularly for plan confirmation, and they are not considered desirable by debtors. ${ }^{64}$ However, many debtors ignore the fact that they should be "small business" debtors and simply proceed under the standard chapter 11 . Sometimes they get caught. ${ }^{65} \mathrm{But}$ mostly, no one objects. ${ }^{66}$ Sometimes the fact that a debtor should have filed as a small business is visible on the face of the petition and accompanying documents, which indicate the amounts and types of debt outstanding. Other times, debtors apparently manipulate their financial statements, for instance by overestimating

\footnotetext{
${ }^{60}$ The creditor would also hold an unsecured "deficiency" claim for the remainder of its claim, but this would usually be paid off at some inconsequential, pennies-on-the-dollar rate and discharged. See 11 U.S.C. $\S 506(\mathrm{a})(1)$; Bonapfel, supra note 1, at 618-24.

${ }^{61}$ See 11 U.S.C. § 1123(b)(5); see also id. § 1322(b)(5) (outlining a similar provision in chapter 13). But see id. $\S 1322(\mathrm{c})(2)$ (providing for a limited exception in certain chapter 13 cases).

62 See 11 U.S.C.A. § 1190(3) (West 2019).

${ }^{63}$ Total liquidated, noncontingent debt must be no more than $\$ 2,725,625.11$ U.S.C. $\$ 101$ (51D)(A). Half of liquidated, noncontingent debt must be from business activity. Id.

${ }^{64}$ See supra text accompanying notes $18-24$.

${ }^{65}$ See, e.g., In re Display Grp., Inc., No. 10-75502-AST, 2010 WL 4777550, at*1 (Bankr. E.D.N.Y. Nov. 16, 2010) (upholding U.S. Trustee's challenge the debtor's failure to designate itself as a small business and applying the small business deadlines not as of the date of the successful challenge but rather as of the petition date).

${ }^{66}$ See supra note 15 and accompanying text.
} 
total debt, in order to ensure that they will exceed the small business limits. In any case, the reality is that, whether due to inattentiveness from courts and trustees or gamesmanship by debtors, most small businesses likely will have the option to file under the new subchapter $\mathrm{V}$, the standard small business provisions, or standard chapter 11 . Thus, standard chapter 11 is likely to continue to serve as a baseline against which debtors and creditors weigh the effects of a potential election into subchapter V.

Creditors could try several strategies to keep debtors from electing into subchapter V. Most obviously, in the course of negotiating with a debtor concerning a loan, a workout, or a forbearance, a creditor could require the debtor to agree in advance not to elect into subchapter V. Such a waiver of the right to elect into subchapter $\mathrm{V}$ may or may not be enforceable. Blanket waivers of the right to file bankruptcy are almost always held unenforceable as a matter of public policy; a debtor cannot waive legal rights to a collective bankruptcy proceeding intended to benefit all parties in interest. ${ }^{67}$ But the law regarding many other forms of waiver or limitation of rights in bankruptcy - such as a waiver of the right to challenge a motion to lift the automatic stay-remains unsettled. ${ }^{68}$ Some courts find that agreements made as part of forbearance or other negotiations after the debtor has encountered distress should be favored because public policy commends out-ofcourt resolutions. ${ }^{69}$

The public policy argument against a subchapter $\mathrm{V}$ waiver is weaker than with complete bankruptcy waivers. A subchapter $\mathrm{V}$ waiver does not remove the debtor from a collective bankruptcy proceeding entirely. Rather, it essentially channels debtors into the law as it stood prior to February of 2020. Against the waiver, however, one might argue that congressional intent was to provide small businesses with this extra chance to succeed. Courts might or might not find this persuasive. In any case, creditors should consider negotiating for a prebankruptcy waiver of the right to elect subchapter $\mathrm{V}$, which might be a useful bargaining chip, even if it might be unenforceable if tested in court.

In addition to an outright waiver, a creditor could seek a springing guarantee (sometimes colloquially referred to as a "bad boy" guarantee), providing for an

\footnotetext{
${ }^{67}$ See, e.g., In re Lexington Hosp. Grp., LLC, 577 B.R. 676, 683 (Bankr. E.D. Ky. 2017) ("It has been said many times and many ways. Prepetition agreements purporting to interfere with a debtor's rights under the Bankruptcy Code are not enforceable." (internal alterations and quotation marks omitted) (quoting In re Intervention Energy Holdings, LLC, 553 B.R. 258, 263 (Bankr. D. Del. 2016))); see also Cecily A. Dumas \& David S. Forsh, Considerations in Evaluating LLC Operating Agreement Constraints on Voluntary Filings, 36 AM. BANKR. INST. J., Dec. 2017 at 26-27.

${ }^{68}$ See Dumas \& Forsh, supra note 67, at 26-27; see also In re Atrium High Point Ltd. P'ship, 189 B.R. 599, 605 (Bankr. M.D.N.C. 1995) (discussing governing principles).

${ }^{69}$ See Wells Fargo Bank Minnesota, N.A. v. Kobernick, No. C.A. 8-CV-1458, 2009 WL 7808949, at *7 (S.D. Tex. May 28, 2009) (collecting cases); In re Atrium High Point Ltd. P'ship, 189 B.R. at 607 ("This is not a situation where a [waiver] . . . was inserted in the original loan documents. The Debtor received significant benefits [pursuant to negotiations]. In exchange for these benefits, the Debtor bargained away its right to oppose a motion to lift stay....").
} 
insider of the debtor to guarantee the debtor's liabilities to the creditor in the event the triggering condition is met-in this case, if the debtor elects into a subchapter $\mathrm{V}$ proceeding. ${ }^{70}$ Although springing guarantees may also implicate public policy concerns, they are more likely to be enforceable than waivers by the debtor, because the direct consequence of the condition being met is borne by a third party, the guarantor. ${ }^{71}$

In addition to the subchapter $\mathrm{V}$ election, creditors may also develop strategies related to debtors' eligibility. The limit for a debtor's "noncontingent liquidated secured and unsecured debt"72 was originally set at the relatively low number of roughly $\$ 2.7$ million, to be inflation adjusted; in light of the COVID-19 pandemic, that number was adjusted to $\$ 7.5$ million for a year, ending late March $2021 .^{73}$ Debts of affiliates of the debtor to outside parties are included in the cap, but the cap expressly omits "debts owed to 1 or more affiliates or insiders. ${ }^{174}$ It is possible that debtors seeking subchapter V eligibility will try to game the eligibility cap. For instance, a debtor might employ mechanisms to assign debts to non-affiliate insiders; might characterize debts as contingent or nonliquidated, without a particularly firm evidentiary basis, assuming that its characterization is unlikely to be challenged; or might lower the amount of debt immediately prior to bankruptcy through agreements with creditors that are willing to take a pre-petition "haircut" in order to support the filing. ${ }^{75}$ These financial maneuvers, and others yet more sophisticated, are likely to be strategies of creative debtors and their creditor allies.

\footnotetext{
${ }^{70}$ On these types of tools in general, see Julie Satow, Bad Boy' Guarantees Snarl Billions in Real Estate Debt, N.Y. TiMES (Jan. 19, 2011), https://www.nytimes.com/2011/01/19/business/19guarantee.html. Various similar mechanisms are explained in detail in Joshua L. Eisenson, Note, Exploring the Enforceability of PrePetition Hindrance Mechanisms to Prevent Bankruptcy, 22 AM. BANKR. INST. L. REV. 247 (2014).

${ }^{71}$ See, e.g., Liberty Mut. Ins. Co. v. Greenwich Ins. Co., 417 F.3d 193, 199 (1st Cir. 2005) ("The bond is an independent obligation of [the third party] . . . which happens to have been triggered by [the debtor's] ... non-payments of debts and resort to bankruptcy."); Chanel Van Dyke, Note, The Invocation Of $\$ 105$ To Bar the Enforcement of Springing Guaranties Triggered by Bankruptcy-Related Events, 20 FORDHAM J. CORP. \& FIN. L. 785, 888-92 (2015) (summarizing cases). Arguments against such springing guarantees include that they are (obviously) intended to affect the exercise of managerial discretion, thus potentially undermining other laws and duties, such as fiduciary duties of officers of business organizations. But such an argument is somewhat difficult to sustain, given that most jurisdictions seem increasingly willing to enforce agreements dispensing with traditional duties or restricting exercises of discretion by officers, even those implicating fiduciary duties. See, e.g., Blaustein v. Lord Baltimore Capital Corp., C.A. No. 6685-VCN, 2013 WL 1810956 , at $* 13$ (Del. Ch. Apr. 30, 2013) (enforcing contractual agreement regarding share repurchase rights and declining to find breach of fiduciary duties).

7211 U.S.C. § 101(51D) (2018).

${ }^{73}$ Coronavirus Aid, Relief, and Economic Security Act, S. 3548, 116th Cong., 2d Sess. (2020) (enacted). The prominent American Bankruptcy Institute Commission, which influenced the Act in numerous respects, had recommended that the threshold be set at $\$ 10$ million. See ABI Commission Report, supra note 1 , at 284-88.

7411 U.S.C. $\S 101(51 \mathrm{D})(\mathrm{B})(\mathrm{i})$

75 This might include creditors that want or need to do business with the debtor going forward, or a secured creditor willing to waive a deficiency claim in whole or in part since it is, in any case, likely to be repaid minimally if at all.
} 
If a hostile creditor suspects the debtor that made the election should not qualify for subchapter $\mathrm{V}$, it faces a decision as to whether to object to the election, and if so, how aggressively to do so. Often, it may not be worth the fight. The debtor benefits from considerable informational and evidentiary advantages concerning questions about its own finances. In most cases, this access gives the debtor an all but insurmountable advantage over any objector.

A low-cost step for a suspicious creditor is to call and communicate its suspicions to the subchapter $\mathrm{V}$ trustee. ${ }^{76}$ Of course, a subchapter $\mathrm{V}$ trustee has little incentive to challenge the debtor's initiation of a case. In one early case that was dismissed prior to plan confirmation upon the debtor's motion, the trustee appears not even to have received payment for her activities prior to the dismissal. ${ }^{77}$ But if the case's collapse begins to appear inevitable, a trustee may be willing to hasten the end, leaving the trustee to move onto more promising work.

If those steps do not yield fruit, the creditor could itself file an objection to the election, or seek discovery from the debtor in order to support a potential objection. ${ }^{78}$ Sometimes creditors come into possession of financial information of the debtor before the case, for instance in the course of loan workout negotiations. Such a creditor would of course be better positioned than most to urge a successful objection. A less informed creditor should consider seeking out information from better-informed creditors, if they exist and might be friendly to the cause.

If a debtor faces real risk of having the subchapter $\mathrm{V}$ case dismissed, the mere threat of an objection might provide leverage. Although care would have to be exercised, it is conceivable that a crafty creditor could negotiate some concessions from the debtor (e.g., over the valuation of an item of collateral or the validity of a claim amount) in order to be induced to leave aside further inquiry as to the debtor's subchapter $\mathrm{V}$ eligibility.

A final strategic consideration concerning eligibility and election into subchapter $\mathrm{V}$ arises from debtors in the real estate business. ${ }^{79}$ After the Act, fewer such debtors will be forced into the stringent Single Asset Real Estate (SARE) provisions of the Code; more will qualify for the debtor-friendly subchapter V.

\footnotetext{
${ }^{76}$ Or even the U.S. Trustee, which retains some "watchdog" responsibilities under subchapter V, although it can be expected not to be particularly involved in most cases.

77 See Verified Statement of Subchapter V Trustee, In re Access Entm't, (Bankr. W.D. Ky. Feb. 26, 2020) (No. 3:20-bk-30643). This does not necessarily seem like a correct result under the Code, but anecdotally, I have been told it has happened in a number of other instances already. Trustees may be reluctant to be perceived as fee-motivated this early in the life of subchapter $\mathrm{V}$.

78 This could be done, for instance, through FED. R. BANKR. P. 2004. However, formal discovery takes time. The better course might be to make informal demands for information; if a debtor refuses to answer reasonable requests, this may reflect poorly on it if the matter makes it to court.

79 See 11 U.S.C. $§ 101(51 \mathrm{~B})$ ("The term 'single asset real estate' means real property constituting a single property or project, other than residential real property with fewer than 4 residential units, which generates substantially all of the gross income of a debtor who is not a family farmer and on which no substantial business is being conducted by a debtor other than the business of operating the real property and activities incidental thereto.").
} 
Thus, creditors should remain vigilant if they lend to real estate-focused entities. Creditors should consider protecting themselves by obtaining agreement from debtors to remain within the SARE definition, for instance through covenants, corporate governance mechanisms, ${ }^{80}$ or springing guarantees, to try to ensure that their debtors remain ineligible for subchapter $\mathrm{V}$.

Because subchapter $\mathrm{V}$ appears to be largely a pro-debtor law, this discussion has assumed that creditors will want to prevent debtors from electing in. However, some creditors may want to force an election into subchapter V. It could be the case, for instance, that a powerful senior secured creditor might consider subchapter $\mathrm{V}$ the most expedient means for its interests to be protected (or more to the point, for general unsecured claims and junior liens to be eliminated).

The approaches above might be adapted to serve those goals. For instance, instead of a waiver of the right to elect, the creditor could negotiate for the debtor to make an agreement to elect into subchapter $\mathrm{V}$, as long as there's a colorable argument that the debtor is eligible. A springing guarantee linked to compliance with this agreement could be put into place. Other strategies could be adapted similarly.

\section{USE THE TRUSTEE STRATEGICALLY}

The least predictable aspect of subchapter $\mathrm{V}$ is the trustee. Even if debtors qualify for subchapter $\mathrm{V}$, and even if it gives them greater leverage against creditors, debtors may hesitate because of the potential costs and risks associated with the trustee. Subchapter V offers benefits to debtors, from administrative streamlining to the redistributive effects from creditors to debtors that it may bring about. But for debtors, the decision of whether to elect likely will depend on whether the advantages this subchapter offers to debtors outweigh the uncertainties and costs added by the trustee.

The statute provides limited guidance concerning what trustees should do. ${ }^{81} \mathrm{In}$ the main run of cases it appears that trustees will not, for instance, be entrusted with any assets to protect, specific constituencies to serve, or concrete duties to perform (aside from filing reports). No one knows how trustees will imagine or inhabit their role, and there seem to be different potential conceptions of the trustee. The two most obvious potential roles are trustee as mediator and trustee as financial analyst. ${ }^{82}$ There is also the possibility that trustees will seek out the role of investigator, which the statute leaves open to them under appropriate circumstances.

\footnotetext{
${ }^{80}$ For example, supermajority or unanimity voting requirements could be imposed as conditions to a bankruptcy filing. Such requirements could be coupled with creditor representation on the board or management group. See, e.g., Dumas \& Forsh, supra note 67, at 75-76.

${ }^{81}$ For a summary, see supra notes 22-27 and accompanying text. See also Bonapfel, supra note 1, at 58385.

82 See, e.g., Swanson, supra note 31, at 77 (discussing potential roles of trustee as "financial wizard" and as plan mediator).
} 
Whatever role they play, the costs of a trustee could be significant. Hourly billing adds up very quickly. Rates will likely range between approximately $\$ 300$ and $\$ 600$ per hour in most districts. ${ }^{83}$ It is hard to see how the trustee can perform any real duties without ten hours of work at a bare minimum.

Small business cases are often small margin cases. Small margin cases could be overwhelmed by trustee fees. Much of the success or failure of subchapter V will depend on what trustees actually do. If they are largely passive intermediaries, costs could be low-although the value added could be even lower. But if the trustee plays a more substantial role mediating between debtor and creditors, or if the trustee engages in serious financial analysis concerning, for instance, the debtor's financial projections, costs could rise very quickly. The very fact that this is so unclear is likely to disturb debtors facing the election decision. ${ }^{84}$

One countervailing fact to weigh against the addition of subchapter V trustee fees is that U.S. Trustee fees will not be assessed. In larger-scale cases, these fees have become a problem for debtors, ${ }^{85}$ but their removal from subchapter $\mathrm{V}$ cases will rarely offer a material cost savings. For small business cases, the fees are manageable. In a case with quarterly disbursements of funds under $\$ 75,000$, the fee as of 2020 is only $\$ 650^{86}$ - a sum that most hourly billers with sufficient experience to serve as trustee would reach in the first morning of their appointment.

Trustees will of course remain subject to whatever discipline may be imposed on them by the court and U.S. Trustee, including the in terrorem effect of not being awarded future appointments. Also, in addition to legal constraints, trustees, who will be drawn from the relatively small community of bankruptcy practitioners within a given district or region, will want to maintain their good reputations. But while these constraints should not be minimized, and while I do not cast doubt on the good faith that can be expected of trustees in general, nonetheless, as for-profit actors, subchapter $\mathrm{V}$ trustees have the incentive to bill as much as they reasonably can without being seen to have overstepped. All of this has several implications for creditors.

First, the creditor should remember that the trustee does not work for the creditor. While the trustee may or may not have been intended as a quasireplacement for the loss of a creditor's committee, the statute simply does not

\footnotetext{
${ }^{83}$ For some examples, see supra note 48 (citing trustees' hourly rates of $\$ 300$ in Western Kentucky and $\$ 550$ in Arizona).

${ }^{84}$ The trustee, in other words, may end up representing an uncertain expense line much like the creditors' committee. On fee risks and uncertainties related to committees in small and medium enterprise cases, see ABI Commission Report, supra note 1, at $293 \mathrm{nn} .1052-54$ and accompanying text. The most useful empirically grounded overview of the role played by committees is Michelle M. Harner \& Jamie Marincic, Committee Capture? An Empirical Analysis of the Role of Creditors' Committees in Business Reorganizations, 64 VAND. L. REV. 749 (2011).

${ }^{85}$ See, e.g., Elizabeth J. Austin, Increase in U.S. Trustee Fees Takes a Heavy Toll on Midsized Debtors, 37 AM. BANKR. INST. J., Sept. 2018 at 38.

86 See 28 U.S.C. § 1930(a)(6) (2018); U.S. Dep't of Justice, ChAPTER 11 QuARTERLY FEES, https://www. justice.gov/ust/chapter-11-quarterly-fees.
} 
instruct the trustee to show particular concern for creditors' interests. Even if trustees occasionally act as mediator and in that role advocate for creditors' interests, they are never required to represent those interests and have no duty to creditors.

To the contrary, trustees are likely to view their central goal as helping to get a feasible plan confirmed, and they may view objecting creditors as obstacles to be overcome or, at best, to be grudgingly appeased. Trustees may seek to make the case run smoothly and in accordance with the broad strokes of the statutory scheme - even at risk of ignoring some "minor" abuses of or infelicities to that scheme. Given that the body of creditors is often dispersed, trustees will likely concentrate on serving the more focused interests of the debtor and on currying the favor of the U.S. Trustee and the court. Although some trustees will be motivated (including by the possibility of billable hours) to investigate potential wrongdoing of the debtor, they are more likely to focus on attaining smooth and speedy confirmation of the plan, which is most likely to please the U.S. Trustee and lead to further appointments.

Second, the trustee's financial interests may directly conflict with those of the unsecured creditors in particular. The fees of the trustee-which, as mentioned, under the new Act may be paid over time as part of the plan-may drain any "disposable income" plan payments that would otherwise go to unsecured creditors. This problem should not be exaggerated; time will tell how severe it is. Perhaps debtors will distribute ample disposable income and trustees will bill sparingly, so that the relationship of trustees, creditors, and debtors is harmonious. On the other hand, a cynic might predict that due to the debtor's (actually or artificially) low disposable income during the plan period, most plans will pay very little if anything to unsecured creditors regardless of the amount of trustee fees incurred. In any case, the underlying conflict of interest is not likely to foster goodwill between creditors and trustees.

Third, it may nonetheless be a good strategy for creditors to seek the help of trustees. Trustees can be effective allies of unsecured creditors with relatively small claims that wish to save fees and remain relatively passive. The trustee's work could save them expenses, which would be borne individually, by representing some of their interests to the debtor and to the court. Where appropriate, creditors may be able to "weaponize" the trustee against the debtor, particularly where the debtor's management may be abusing its position by misusing assets, hiding information, or lowballing the disposable income that will determine plan payments. While subchapter $\mathrm{V}$ trustees are not statutorily charged with investigating the debtor's affairs, most trustees will likely feel uncomfortable ignoring credible complaints, and will undertake to develop at least some view regarding the credibility of debtors' financial information and projections. A "squeaky wheel" strategy may work for a creditor that can articulate concrete and well-founded objections to the debtor's proposed course of action. If trustees seek relief from bankruptcy courts, or express skepticism regarding plans, they will 
likely be given a generous hearing due to their "neutral" status. For this reason, debtors may seek to appease the trustee for fear of the trustee turning on them.

Much depends on the nature of the creditor's claim and its position vis-à-vis the debtor. Less powerful creditors may be well advised to cultivate a relationship with the trustee, whereas powerful creditors probably have more to lose than to gain from any actions by the trustee. A powerful creditor, for instance a secured creditor closely allied with the debtor, may not need the trustee - and may rightly be wary of the trustee. A trustee could be a powerful enemy of such a creditor. A trustee who turns on the debtor may turn on the closely allied creditor as well, threatening expensive and risky proceedings against the creditor, undermining its claims on the estate or relationship with the debtor. Such a creditor may set out a strategy of simply trying to keep the trustee "happy and well fed," keeping the case moving smoothly, and ensuring that fees are paid promptly when approved by the court.

For any creditor, too much aggression comes with risks. If a creditor is perceived to be needlessly adding to administrative costs or encroaching on rights allocated to the debtor by law, the overactive creditor may draw the ire of the debtor, trustee, and the court. At worst, a creditor might be forced to shift into a defensive posture and be drawn into expensive fights. After all, while trustees may be reluctant to investigate the debtor due to the risk of derailing the plan, no such compunction would impede potential investigation of claims against creditors. The exact role of trustees under subchapter $\mathrm{V}$ may be unclear, but at a minimum, trustees have the right to investigate and object to creditors' claims. ${ }^{87}$ Trustees might have to seek court approval in order to expand their role beyond claim objections, but often, courts may be amenable to that expansion, given that trustees will have background knowledge of the case.

If a trustee has proven to be too debtor-friendly, creditors with sufficient motivation should consider numerous steps to obtain greater representation of their interests. One strategy is to request that a creditor's committee be appointed, which the court may order for cause. ${ }^{88}$ Courts may be reluctant, given the extra costs an appointment would impose; but even if the court does not grant such a request, the creditor's goal may be accomplished: A well-argued request may serve as a way of getting the attention of the debtor and the trustee and enlisting the judge to take a more active, managerial role in the case.

A more extreme option is for the creditor to seek to convince the U.S. Trustee, who is entrusted with the supervision of subchapter $\mathrm{V}$ trustees, ${ }^{89}$ to remove and replace the trustee for misconduct or lack of fulfilling required duties. ${ }^{90}$ This is a step that a creditor should only consider if it does not mind alienating the trustee in

8711 U.S.C. $\S 704(a)(5)(2018)$.

${ }^{88}$ Id. § 1102(a)(3).

8928 U.S.C. $\$ 586(\mathrm{a})(3)$.

9011 U.S.C. $\S 324$. 
the (likely) event that the gambit fails. Possibly, the mere suggestion that this step is being considered could get the trustee's attention, although it comes with risks.

If the problem is not so much the trustee but the debtor, a creditor could seek to have the trustee given a more powerful role - even the role of displacing the debtor in possession completely and taking over the entity. The statute allows for this possibility, although the standard is high. ${ }^{91}$ A creditor is well advised to do its homework before filing such a motion. The motion should not be filed without sufficient support. Investigation, even formal discovery, may be necessary. ${ }^{92}$ Ideally, a motion will be accompanied by exhibits, such as financial information or correspondence, raising serious doubts about whether the debtor's management is performing its duties honestly and fairly. Although trustees may hesitate to support such a motion, it favors their financial interests and, thus, trustees may not oppose it. Even if the motion fails, it may succeed in darkening the court's view of the debtor and lay the groundwork for successful resistance to a proposed plan.

In addition to these concrete steps, additional dimensions of "trustee management" will have to be considered at every stage of subchapter V cases, as the remainder of the Article makes clear.

\section{STRATEGIES REGARDING SUBCHAPTER V PLANS}

This Part focuses on the strategic implications of the plan-related provisions of the Act. Section A discusses strategies related to the plan proposal timeline. Section B deals with the "disposable income" requirement and the likely negative effects of cramdown plans on creditors. Section $\mathrm{C}$ discusses the leverage that creditors may be able to gain from the advantages the law gives to consensual plans. Section D proposes ways that creditors can address the lowered disclosure requirements for debtors under subchapter V. Finally, Section E briefly outlines strategies concerning loans secured by a principal residence of the debtor.

\section{A. Keep the Case Moving}

Subchapter V leaves ample room for debtors to extend their cases and delay plan confirmation. Delays will impact creditors differently. Those with sufficient security or priority may not be injured by delay, whereas for other creditors, a lengthy stay in bankruptcy may give the debtor the opportunity to squander any value from which they might have recovered. While delay cannot be explicitly parlayed into concessions, those that control the timeline of a case will have considerable leverage over those damaged by the delay, and they can be expected to act strategically along this dimension. Creditors negatively impacted by delay in

\footnotetext{
${ }^{91}$ See id. § 1104(a) (standard for replacement of debtor in possession); 11 U.S.C.A. § 1183(b)(5) (West 2019) (duties of trustee if debtor in possession is removed).

92 See infra notes 71-76 and accompanying text (discussing discovery tools).
} 
the plan process should consider strategies to discipline debtors and keep cases moving toward their conclusion.

Under subchapter $\mathrm{V}$, only the debtor may propose a plan, and unlike standard chapter 11 cases, this exclusivity period never expires. ${ }^{93}$ In addition, while a debtor must propose a plan within ninety days of the petition date, the law does not require confirmation be accomplished by any particular time. Nor does it restrict the number, or types, of modifications that may be made to a plan. ${ }^{94}$

The lack of a deadline for confirmation or of limitations on plan modification may present serious concerns for creditors. Debtors may well develop the practice of filing placeholder plans early in the case and then modifying them over timeperhaps over great lengths of time. In the absence of statutory guidance concerning the permissibility of such behavior, creditors may appeal to the court for relief. The legal basis to end a subchapter $V$ case would be to seek its dismissal or conversion to chapter 7 liquidation. Relief should be granted if the facts show that the debtor cannot likely confirm a plan and reorganize in a reasonable amount of time, ${ }^{95}$ but the test is sufficiently amorphous that creditors will have to rely on the case-by-case "horse sense" of the court. Courts may be lenient towards debtors, particularly if a trustee is willing to vouch for the debtor's good faith effort at confirmation of a plan. Thus, creditors may find it worthwhile to seek to convince or cajole the trustee into taking a more skeptical position toward the debtor if the plan process seems to be unnecessarily extended or the plan itself seems to be unrealistic.

The statute requires courts to hold a status conference within sixty days of the petition date and debtors to file a report concerning their efforts and the progress of the case, two weeks prior to that conference. ${ }^{96}$ Debtors can be expected to claim that they are working assiduously toward an eminently reasonable and confirmable plan, and that they are ready to move toward confirmation as soon as they have the next seasons' sales data, or their accountants' projections, or confirmation of an investment that is still under discussion, and so on. For impatient creditors, it is important that such statements not go uncontroverted where there are articulable reasons for doubt.

Despite the absence of concrete deadlines, the subchapter V scheme evidences an overall intention for cases to be prosecuted expeditiously by debtors. The status conference may be an apt time to impress the need for haste and the cost of delay upon the debtor and the court. Creditors may find it worthwhile to review the debtor's pre-conference filing carefully and perhaps even present their concerns in a

\footnotetext{
93 Compare 11 U.S.C.A. § 1189(a) (subchapter V), with 11 U.S.C. § 1121(e) (general small business chapter 11).

${ }^{94}$ See supra notes $18-21$ and accompanying text.

9511 U.S.C. § 1112(b)(4).

${ }^{96} 11$ U.S.C.A. § 1188(a), (c).
} 
filing prior to the conference. ${ }^{97}$ If creditors emphasize the costs of delay, the court is more likely to do its part and pressure the debtor to make progress.

If plan modifications stretch on, or vary from the original plan in a particularly radical manner, creditors may be able to build a case that the debtor's management does not have a sufficient handle on the debtor's actual or likely financial circumstances, or that the actual goal of the process is speculation and delay rather than reorganization. It may be possible to state or imply - or threaten to state or imply - that the debtor has abused the process or acted in bad faith, which may give a creditor leverage in negotiations over plan confirmation. At the initial status conference, the creditor may wish to request that the court hold another status conference in thirty or sixty days, ${ }^{98}$ at which point the court may more seriously consider any doubts that the creditor raised in the first status conference and that have been left unaddressed by the debtor.

\section{B. Mitigate the Damage of Cramdown}

Nonconsensual or "cramdown" plans under subchapter V differ from other chapter 11 plans in that they require calculating the debtor's "disposable income," and provide that if such amount is dedicated to plan payments, then (a) the plan can be confirmed even in the absence of any impaired consenting class of creditors, and (b) the debtor's current ownership can remain in place notwithstanding the "absolute priority" rule. ${ }^{99}$ Even in consensual plans, the debtor's disposable income presumably will be the primary baseline against which payments to creditors will be negotiated. Thus, debtors and creditors alike are likely to focus on how this amount is determined.

The statutory definition of disposable income requires the debtor to subtract certain expenses from the debtor's projected revenue during the plan period of three to five years. The difference is the debtor's disposable income, which must be devoted to plan payments. The expenses include "expenditures necessary for the continuation, preservation, or operation of the business of the debtor," as well as certain domestic support obligations (where applicable). ${ }^{100}$

The disposable income requirement seems very easily gamed by subchapter $\mathrm{V}$ debtors. ${ }^{101}$ Creditors are likely to view the disposable income test as an invitation to

\footnotetext{
${ }_{97}$ As commentators have noted regarding prior bankruptcy law, "[n]early any effort to bring the issue of speed before the court, successful or not, is likely to cause the case to move more quickly." LOPUCKI \& MIRICK, supra note 5, at 640.

${ }^{98}$ See 11 U.S.C. $\$ 105(\mathrm{~d})$.

9911 U.S.C.A. $\S 1191(\mathrm{~b})$.

${ }^{100} I d . \S 1191(\mathrm{~d})(2)$.

${ }^{101}$ This requirement most closely resembles chapter 12, but I am unaware of any literature weighing the effectiveness of it in those cases, which remain relatively rare. In chapter 13, despite extensive efforts by Congress to regulate and systematize debtors' budgets, practitioners readily (privately) admit that manipulation of either projected revenue or projected expenses is, common, to garner some "cushion" for unexpected expenses or to raise the likelihood of confirmation or both. See, e.g., David R. Jones, Savings:
} 
mischief. Debtors will have every incentive to lowball their projected revenues and to maximize their projected expenses, leaving a fig leaf of a plan payment to unsecured creditors beyond what is required to pay priority and secured claims. Expenditures of all sorts might well be argued to be "necessary for the ...preservation"102 of the debtor, and management will likely be given significant flexibility in its plans to recover from financial distress. In the course of their painful descent into bankruptcy, debtors have commonly neglected maintenance and other expenses. The debtor's rational course of action is to project the plan period as a time when profits should be minimized in favor of putting the venture on sound footing. Thus, the entity will be in better shape when the plan is over, and the debtor's owners will once again be able to attain a return on their investment. In fact, the owners can begin to benefit from their investment during the plan period; if the projected disposable income is lower than the actual profits, there is no requirement to modify the plan to share the additional money with creditors.

Projections of debtors' income and expenses are not unknown in modern chapter 11 cases, where debtors commonly produce detailed budgets before being permitted to use cash collateral in pursuit of their reorganization. ${ }^{103}$ But there are important distinctions between those budgets and the subchapter $\mathrm{V}$ disposal income projection. First, cash collateral budgets rarely stretch more than a few months in small-sized or medium-sized cases, whereas subchapter $\mathrm{V}$ projections will stretch three to five years into the future. Second, more importantly, we have every reason to expect less energetic monitoring of a subchapter $\mathrm{V}$ projection. Unlike a cash collateral budget in chapter 11, where you have a well-informed secured creditor interested in the destination of each dollar, there is much less pressure on the disposable income calculation. The debtor will be obligated to make sure that the plan pays administrative, secured, and other priority claims in full through the plan, ${ }^{104}$ but beyond that, every dollar will be shared pro rata among unsecured creditors with little incentive or ability to nit-pick the debtor's projections. And debtors' finances are often so volatile, in the months leading to bankruptcy, as to make almost any projection three to five years in the future speculative at best.

The problem of disposable income manipulation is exacerbated by the lowered disclosure requirements of subchapter V. Debtors have superior information about

The Missing Element in Chapter 13 Bankruptcy Cases?, AM. BANKR. INST. L. REV. 243, 255-56 (2018) (noting certain budget lines in many chapter 13 are commonly used as "plugs in an unrealistic budget"); $i d$. at $256 \mathrm{n} .81$ (noting "manipulation of budget numbers" can be used to "'create' feasibility in tight plans"). Because subchapter $\mathrm{V}$ lacks the stringent regulations of chapter 13, it may be easier for debtors to manipulate disposable income in subchapter $\mathrm{V}$.

${ }^{102} \mathrm{Id}$.

103 See, e.g., Jon M. Labovitz, Taking a Fresh Look at DIP Budgeting, AM. BANKR. INST. J. (Mar. 2005), https://www.abi.org/abi-journal/taking-a-fresh-look-at-dip-budgeting\#1a. I am grateful to Hon. Tracey Wise for pointing out the analogy (although she bears no responsibility for my conclusions here).

${ }^{104}$ See supra notes 28-30; infra note 109 and accompanying text. 
their own finances and their future prospects, and they will be capable of producing the three to five years of income projections that best suit their preferences. Subchapter V deepens this informational divide in several ways. First, unlike the separate disclosure statement required for standard chapter 11 plan confirmation, debtors in subchapter $\mathrm{V}$ need only disclose certain basic information in the plan itself. The plan need include only a brief history of the debtor's operations, a liquidation analysis, and projections regarding the debtor's ability to fund the plan. ${ }^{105}$ Second, in most chapter 11 cases, creditors' committees, where appointed, are charged with "investigat[ing] the . . . assets . . . and financial condition of the debtor," 106 but subchapter $\mathrm{V}$ dispenses with the committee without reassigning this duty. ${ }^{107}$ The subchapter $\mathrm{V}$ trustee has no general duty to investigate the debtor's financial affairs. As mentioned in the preceding Part, trustees may have little incentive to help unsecured creditors negotiate against the debtor, because trustees are highly likely to focus on the confirmation of the plan, even if it leaves the creditors worse off than a fair disposable income calculation.

In light of these significant challenges, creditors should develop counterstrategies. One piece of advice is relatively simple: Try not to be a general unsecured creditor. ${ }^{108}$ No matter how much the debtor manipulates the disposable income calculation, the plan must provide for payment in full of secured claims, administrative claims, and the cure amounts of executory contracts that the debtor is assuming. ${ }^{109}$ In the time leading up to a potential subchapter $\mathrm{V}$ proceeding - and subject of course to caveats about avoidable transfers ${ }^{110}$ - a creditor at risk of being left in the general unsecured pool would be advised to make every effort to convert a potential general unsecured claim into a secured or administrative claim, or to structure their relationship with the debtor in such a way as to ensure that the debtor will want to cure any arrearages and assume any contract with the creditor. Otherwise they are likely to see little recovery.

Another strategy relates to undersecured creditors choosing whether to make what is called the "section 1111(b) election." Undersecured creditors generally have two claims in a bankruptcy: (1) A secured claim that is capped at the value of

\footnotetext{
10511 U.S.C.A. $\S 1190(1)$.

10611 U.S.C. $\S 1103(c)(2018)$.

107 Id. $\S 1102(\mathrm{a})(3)$

${ }^{108}$ I am indebted to Christopher Mirick and Lynn LoPucki for suggesting this point.

109 Payment with post-confirmation interest will certainly be required for secured claims. 11 U.S.C. $\S 1129(\mathrm{~b})(2)(\mathrm{A})(\mathrm{i})$. Whether it is true of administrative claims is less certain. See Brubaker, supra note 1, at 17; 11 U.S.C.A $\S 1191$ (e) (permitting payment of administrative claims through plan payments). Cure of an executory contract must be made "promptly," see 11 U.S.C. $\$ 365(\mathrm{~b})(1)(\mathrm{A})$. The meaning of this provision varies on circumstances but often means cure must be tendered prior to confirmation or soon after (and should usually include post-petition interest). See, e.g., In re Tama Beef Packing, Inc., 277 B.R. 407, 411 (Bankr. N.D. Iowa 2002) ("Various courts have held that prompt can mean anywhere between two weeks to five years depending on the circumstances of a particular case."); In re Valley View Shopping Ctr., L.P., 260 B.R. 10, 25-26 (Bankr. D. Kan. 2001) (deeming two years prompt, under the circumstances, but requiring post-petition interest to be paid).

110 See, e.g., LOPUCKI \& MIRICK, supra note 5, at 38-53.
} 
their collateral but has to be paid in full with interest under the plan; and (2) an unsecured claim for the deficiency, usually paid at pennies on the dollar. ${ }^{111}$ Section 1111(b) of the Bankruptcy Code provides an opportunity for the creditor to change this treatment. ${ }^{112}$ If it so chooses, an undersecured creditor can sacrifice its unsecured deficiency claim and, in exchange, retain the full amount of its secured claim and its lien on the debtor's collateral. While the expanded secured claim need not be paid with interest, it has to be paid at some point, in nominal dollars, in the debtor's plan. ${ }^{13}$ This means that when a creditor takes the section 1111(b) election, plans often are stretched out for many years - sometimes decades.

Such creditors should consider taking the section 1111(b) election. As this Article has already shown, subchapter $\mathrm{V}$ diminishes the value of unsecured deficiency claims of undersecured creditors in several ways: through the low likelihood of receiving significant plan payments, the end of the absolute priority rule, and the removal of the requirement of an impaired class accepting the plan. ${ }^{114}$ This should have the effect of encouraging undersecured creditors to take the section 1111(b) election more often under subchapter V than in standard chapter 11. However, this may be true only when the unsecured deficiency claim is not large enough to allow the undersecured creditor to control the vote of the general unsecured class - an important possibility discussed at length in the following section.

Debtors are unlikely to relish any increased use of the section 1111(b) by creditors. Not only will plan payments last much longer than the initial three-tofive-year period, but also secured creditors will retain their liens much longer. ${ }^{115}$ Both of these facts could weigh on profitability and complicate debtors' options with respect to financing. Thus, creditors with the power to make the election may be able to extract favorable treatment from the debtor. ${ }^{116}$

In the end, these steps may not be much help except in extreme circumstances. The plan provisions are in many ways the core of subchapter $\mathrm{V}$, and they are very debtor-friendly. Given their lack of risk and their privileged access to the relevant information, owners can be expected to propose aggressive plans, and even with the strategies outlined above in hand, many creditors will have little ability to check the debtor.

\footnotetext{
11111 U.S.C. $\$ \S 506(a), 1129(b)(2)(A)(i)$

112 Under the relevant Interim Rule of Bankruptcy Procedure, the court must set a date by which the election must be made. INTERIM R. BANKR. P. 3014, https:/www.uscourts.gov/sites/default/files/2019_sbra interim_rules_amendments_redline_0.pdf.

11311 U.S.C. § 1111(b); LOPUCKI \& MIRICK, supra note 5, at 784-87.

${ }^{114}$ See supra notes $18-21$ and accompanying text.

115 On the interaction between the three-to-five-year period for disposable income and discharge, versus the longer period for paying other debts through the plan, see supra note 21 and accompanying text.

116 It bears noting that the ABI Commission recommended removing the ability to take the 1111(b) election in small business cases, although its advice was not heeded by Congress. See ABI Commission Report, supra note 1, at 296.
} 
The upshot of the disposable income requirement is that a subchapter V plan is a call option for a debtor's owners, funded by the creditors. The risk of failure is offloaded to creditors, while the upside goes to the debtor's owners. ${ }^{117}$ After all, the debtor's owner-controllers are paid for their services while the plan is working. ${ }^{118}$ If the plan fails and the entity is liquidated, the creditors are left with little if anything, while the debtor's owners move on to their next enterprise. But if the venture does well, the controllers keep all funds in excess of the projections, and, of course, they keep the long-term value of the firm. The plan payment amount is the most the creditors will receive; the owners of the debtor receive the remaining upside, during and after the plan period.

\section{Extract Concessions for Plan Approval}

Subchapter $\mathrm{V}$ assigns different legal consequences to plans approved by creditors rather than forced on them by "cramdown." Passing a consensual plan has three significant effects, all of which seem likely to motivate the debtor to seek creditors' acceptance of its plan: earlier termination of the trustee's appointment, earlier discharge, and the right to keep post-petition property free of the bankruptcy estate. Because debtors are likely to prize these incentives, there will be leverage here for creditors whose votes are necessary for plan confirmation. Creditors should seek to exploit whatever leverage they have to block consensual confirmation until they have extracted all they believe they can get from the debtor.

First, the trustee is automatically terminated upon substantial consummation of a consensual plan, whereas, when the plan is confirmed on a cramdown basis, the trustee's appointment will remain in place and the trustee will be obligated to administer plan payments. ${ }^{119}$ The additional fees could be consequential. As noted above, currently, trustees appointed under the Act are billing hourly, with a range of roughly $\$ 300$ to $\$ 600$ per hour. Adding thousands of dollars to a small-margin plan such as that necessary for most subchapter $\mathrm{V}$ cases could be the difference between its success and its failure, or its feasibility and its infeasibility.

The trustee-retention provision is puzzling. The trustee serves no necessary role after confirmation. The additional trustee fees seem to be a deadweight loss imposed to attempt to bludgeon parties into agreement. It is worth noting that the

\footnotetext{
117 A call option gives the owner all of the upside but none of the downside of an asset or investment. More technically, a "call option" is a financial contract that gives its owner the right, but not the obligation, to buy something at a set price. If the object rises in value beyond the set price, then the option owner can "exercise" the option and buy the object at the bargain price. If the object declines in value, the option owner simply lets the option expire and is not out any money. See Justin Kuepper, Call Option Definition, INVESTOPEDIA, https://www.investopedia.com/terms/c/calloption.asp (last updated May 26, 2020).

118 Wages for management are "expenditures necessary for the continuation, preservation, or operation of the business of the debtor" and should be included as the expenses that are deducted in calculating the "disposable" income. 11 U.S.C.A. § 1191(d) (West 2019).

${ }^{119}$ Id. § 1183(c)(1).
} 
statute gives the court authority to depart from this usual course and dismiss the trustee if so "provided in the plan or in the order confirming the plan." ${ }^{120}$ One could imagine that requests to dismiss trustees (or dramatically restrict their duties), even in nonconsensual cases, might become commonplace, and that courts might sensibly adopt the habit of granting such requests. This provision might be used more often than the many other possible places where the court is permitted to deviate from the standard subchapter $\mathrm{V}$ rules. It is also unclear how much trustees will on average charge for post-confirmation services, which should be fairly mechanistic.

In any case, and notwithstanding these provisos, the potential retention of a trustee is intended to motivate the negotiation of consensual plans, and it will likely do so. It will particularly motivate the debtor to make concessions in order to reach consent.

Not all share this view. In his astute Bankruptcy Law Letter on the Act, Professor Brubaker suggests that this factor will motivate creditors to confirm consensual plans too. ${ }^{121} \mathrm{He}$ argues that this is because they will want to avoid the trustee collecting fees out of a debtor's plan payments that would otherwise be directed to them. ${ }^{122}$ And indeed, Brubaker is correct that in some instances, for example when there is sufficient income to make meaningful payments to unsecured creditors, the body of creditors would benefit from consensual confirmation. But in many (I predict most) cases, where the debtor is desperately trying to propose a minimum confirmable plan-which requires paying secured and priority (including administrative) claims in full - the threat of adding to the administrative claims will provide leverage to creditors whose votes the debtor needs, so that the debtor can avoid ongoing trustee fees.

Further, an individual creditor in a blocking position may be willing to sacrifice the interests of the other members of the creditor class if it can extract more from the debtor for itself. Consider a creditor with claims amounting to $40 \%$ of the general unsecured class, which therefore is in a position to block consensual plan confirmation. If such a creditor can extract concessions worth more than $40 \%$ of the trustee's additional fees, then it has an incentive to do so.

As noted earlier, ${ }^{123}$ one of the motivations for subchapter $\mathrm{V}$ was to limit the power of undersecured creditors with large deficiency claims (as is common in modern chapter 11), which often control the vote of the general unsecured class. Subchapter V may have removed these creditors' veto power over confirmation of

\footnotetext{
${ }^{120}$ Id. § 1194(b).

${ }^{121}$ See Brubaker, supra note 1, at 11.

$122 \mathrm{Id}$. at 12 ("[C]reditors will prefer to avoid the fees the Subchapter V trustee will collect from the debtor's plan payments (before payments to creditors) if confirmation is via cram-down.").

${ }^{123}$ See supra notes $18,21,111-116$ and accompanying text.
} 
plans, but such creditors retain the ability to block consensual plan passage. ${ }^{124}$ Because they can inflict pain on the debtor and to some degree the other creditors, they retain considerable leverage.

Saving on fees is not the only reason the debtor will be motivated to bring the trustee's appointment to an end. Removing the trustee reduces supervision over the debtor, giving managers and owners a freer hand. This factor is, by contrast, detrimental to the body of creditors. For this reason, too, creditors with significant voting power may demand more in exchange for their consent.

Second, and unlike non-consensual plans, debtors with consensual plans receive an immediate discharge. ${ }^{125}$ This difference is particularly stark for individuals in chapter 11. Under the standard chapter 11 rules, individuals receive their discharge only after all plan payments are made - which means that because many plans fail, many debtors never receive such a discharge. ${ }^{126}$ Thus, the only way that individuals may receive an immediate discharge is under subchapter $\mathrm{V}$, and through a consensual plan. Again, this provides well-positioned creditors with leverage.

Finally, by contrast to standard chapter $11,{ }^{127}$ subchapter V provides that postpetition property becomes property of the bankruptcy estate, but only if the debtor confirms the plan non-consensually. ${ }^{128}$ This does not mean that all of that property must be paid out to creditors; only payments pursuant to the plan are required, and there does not appear to be any mechanism for creditors to seek modification of the plan if the debtor's fortunes change for the better. But it does mean that the automatic stay should continue to protect property of the estate from collection efforts (although this would only matter if the debtor was not paying its debts). ${ }^{129}$ More disruptively for the debtor, it means the debtor needs court approval to use the property outside of the ordinary course of business. ${ }^{130}$

On balance, creditors probably would prefer property to remain in the estate. Creditors entitled to payments under the plan might prefer for the debtor to have to request extraordinary uses of its property, so that they can monitor and object if necessary. They might also prefer for the automatic stay to remain in place; if another creditor seeks to lift the stay, it would be a warning that the debtor might be in financial trouble. Moreover, in the event that the plan fails, the creditor might be

\footnotetext{
124 See Brubaker, supra note 1, at 11-12,14-15 (noting even if it is to be paid the full value of its claim under the plan, a class can not only reject the plan but also force the disposable-income requirement to be met).

125 See 11 U.S.C.A. $§ 1181$ (c) (providing that with a nonconsensual plan there is no immediate discharge pursuant to 11 U.S.C. $\S 1141(\mathrm{~d}))$.

12611 U.S.C. $\$ 1141(\mathrm{~d})(5)(2018)$

127 Id. $\$ 1115$.

12811 U.S.C.A. $\S 1186$.

12911 U.S.C. $\$ 362(a)$. The continued application of the automatic stay is not necessarily a negative factor for debtors and might give them more breathing room when they encounter financial difficulties, since creditors will have to go to the court for relief. On the other hand, this potential positive is unlikely to be outweighed by the extra supervision of courts and creditors over property of the estate.

${ }^{130}$ Id. $\S 363(\mathrm{~b})$.
} 
able to collect from assets of the estate quicker, rather than having to try to resort to normal collections efforts to recover from the debtor's property. For their part, debtors are likely to want to avoid their property continuing to be part of the bankruptcy estate, in order to avoid court monitoring and to maintain a freer hand in the use of their property. Therefore, this feature of subchapter $\mathrm{V}$ may provide some leverage for creditors.

In sum, most or all of the benefits of consensual confirmation flow to the debtor. Creditors with voting power should have significant leverage and may be expected to negotiate hard before consenting to a plan. They should seek to force the debtor to distribute some additional benefits to them in exchange for their consent. As mentioned, "consensual" does not mean "unanimously approved"; certain creditors may have blocking positions on their own, ${ }^{131}$ but others may have little to no ability to affect a plan's ability to be confirmed on a "consensual" basis under the bankruptcy voting rules. Creditors that have the power to block consensual confirmation may be able to extract significant concessions from debtors, due to the implications of the stark distinction between consensual and nonconsensual plans.

The form of the concessions will depend on the position of the creditor and the nature of the plan. Some benefits, such as higher payments to all general unsecured creditors, may be shared among the creditors as a whole. Others, such as agreement to a higher valuation of particular collateral, to a desired release against potential claims of the estate against the creditor, to particular remedies should the debtor default on plan payments, or to additional fees and claims, may be specific to one creditor. Consider again the example of an undersecured creditor with a large deficiency claim - ideally, large enough to control the acceptance or rejection of the plan. That creditor would be well-positioned to extract concessions regarding its secured claim, for instance the valuation and the interest rate that it will be paid on account of that claim, in exchange for delivering the debtor the votes needed for consensual confirmation.

Given that many small business plans will not succeed, creditors should consider taking their concessions in the form of the "remedies, which may include the liquidation of nonexempt assets, to protect the holders of claims or interests in the event that the payments are not made." ${ }^{132}$ Creditors should consider negotiating for plans to provide for retention of a lien or for a new security interest, or to specify particular remedies upon default. The rights to speedily seize and sell or otherwise look for collection from the debtor's assets upon failure of the venture might prove very valuable.

\footnotetext{
${ }^{131}$ Secured creditors are usually in classes of their own; an unsecured creditor with a large claim may be able to dominate its class; and individual administrative creditors may also have the power to block a consensual confirmation. See supra note 32 and accompanying text.

13211 U.S.C.A. § 1191(c)(3)(B) (requiring plans to "provide[] appropriate remedies, which may include the liquidation of nonexempt assets . . . in the event that the payments are not made").
} 


\section{Obtain Information}

Subchapter V will leave creditors less informed. The combined effect of the failure of the Act to charge the trustee with investigating the debtor's affairs, the lack of a creditor's committee, and the lowered requirement of plan-related disclosures - particularly when combined with the centrality of the debtor's projection of "disposable income" in the plan process - are likely to add up to a disaster from many creditors' perspectives. Creditors should consider several possible steps if more information might help their strategic decision-making.

First, even under subchapter $\mathrm{V}$, debtors will have to appear at a meeting of creditors to answer questions. ${ }^{133}$ Although some debtors do not take this obligation particularly seriously (and it is unclear what sanctions are available when they do not), the meeting may present an opportunity for a well-prepared creditor to pin the debtor down on some key issues early in the case. The status conference to be held within sixty days of the petition date is also a potential opportunity for accountability, as mentioned above. ${ }^{134}$

Second, debtors have to provide financial information at the beginning of the case, as well as monthly reports throughout the case. ${ }^{135}$ If review of those materials permits a creditor to catch material inaccuracies and bring them to the court's attention (or even just the trustee's attention), the debtor may lose credibility.

Third, creditors should remain aware of their power to seek documents or testimony pursuant to the powerful Bankruptcy Rule 2004, which provides that "[o]n motion of any party in interest, the court may order the examination of any entity," ${ }^{136}$ including examination of "the acts, conduct, or property or . . . the liabilities and financial condition of the debtor, or . . . any matter which may affect the administration of the debtor's estate, or . . . the debtor's right to a discharge."137 Document requests, depositions, and other forms of discovery are routinely permitted under this rule, and courts have given full scope to Rule 2004's "permissive language"-_"Rule 2004 examinations are broad and unfettered and in the nature of fishing expeditions." ${ }^{138}$ Even if a creditor does not want to incur the

\footnotetext{
${ }^{133}$ See id. $\S \S 341,343$ (explaining the procedure for convening a meeting of creditors as well as noting the debtor's duty to appear).

${ }^{134}$ See supra notes $68-71$ and accompanying text.

135 See 11 U.S.C.A. $\S 1187$.

${ }^{136}$ FED. R. BANKR. P. 2004(a).

137 FED. R. BANKR. P. 2004(b)

138 See In re Enron Corp., 281 B.R. 836, 840 (Bankr. S.D.N.Y. 2002). That said, because Rule 2004 examinations can be expensive, courts in practice restrict examinations that are duplicative, vexatious, or not reasonably likely to improve recovery of assets for the estate. See, e.g., In re Drexel Burnham Lambert Grp., 123 B.R. 702, 711 (Bankr. S.D.N.Y. 1991) ("[The 'fishing expedition' permitted under Rule 2004] can net the dolphins as well as the tuna; however, the net, in the discretion of the Court, can be carefully stitched to limit its catch."); In re Countrywide Home Loans, Inc., 384 B.R. 373, 391-92 (Bankr. W.D. Pa. 2008) (restricting discovery sought to U.S. Trustee in part on grounds of expense).
} 
expense of a deposition, a document request can be easily prepared, and it may help get the debtor's attention and give the creditor leverage.

Fourth, even after plan confirmation, creditors may wish to monitor the debtor's finances and expenditures to the degree possible, for instance by reviewing court filings or reports the debtor may be required to make, by requesting information from the trustee, or even by seeking discovery from the debtor. If a creditor can show that the debtor has not made identifiable, projected expenditures, then there may be an argument that the debtor has abused the bankruptcy process. The creditor might even be able to bring claims or seek sanctions against the debtor or its management for such bad-faith action. On the other hand, subchapter V does not provide creditors with any rights to seek modification of a plan, including on grounds that the projections were too low. As long as the debtor's projections were not evidently in bad faith, the debtor will retain any surplus above the plan payment amount.

\section{E. Prevent Mortgage Modification}

The power to modify loans secured by a debtor's principal residence in subchapter V represents a new risk for creditors. ${ }^{139}$ Modification of principal residences is usually not permitted in bankruptcy, apparently on the theory that it would threaten the housing market, for instance, by encouraging strategic modification by debtors when house prices were abnormally low. ${ }^{140}$

Section 1190(3) states that a subchapter V plan "may modify the rights of the holder of a claim secured only by a security interest in real property that is the principal residence of the debtor," provided that the mortgage does not emerge from a purchase money loan and that it was "used primarily in connection with the small business of the debtor." 141 Notably, the Act defines "debtor" to include both the particular debtor in the particular bankruptcy case and "any affiliate of such person that is also a debtor under this title."142 This is relevant because individuals who own entities often are required to guarantee loans to the company and to offer their residence as collateral. If the venture fails, both entity and individual may file under subchapter $\mathrm{V}$, and the guarantee secured by the house may be at risk of modification under subchapter V. Creditors taking a debtor's residence as

\footnotetext{
139 See 11 U.S.C.A § 1190(3). Some vigilance was already required, of course. After all, the Bankruptcy Code does not prevent modifications of a residence that ceases being the debtor's principal residence. See, e.g., Lynn M. LoPucki, House Swaps: A Strategic Bankruptcy Solution to the Foreclosure Crisis, $112 \mathrm{MiCH}$. L. REV. 689, 690-91 (2014) (proposing a widespread scheme to evade consequences of "principal residence" restriction).

14011 U.S.C. $\S \S 1123(b)(5), 1322(b)(2)$.

14111 U.S.C.A. $\S 1190(3)$.

${ }_{142} I d$. $\S 1182(1)(\mathrm{A})$. I am grateful to Lynn LoPucki for helping me perceive the importance of this definition.
} 
collateral, including through a guarantee, should consider strategies to protect themselves against this law. ${ }^{143}$

To protect against modification, creditors should consider requiring personal expenditures to consume more than half of the loan. A creditor should endeavor to track the loan funds to establish an evidentiary record to support the veracity of that representation should the debtor later seek to contradict it. This may be difficult if the loan is merely a guarantee of a small business loan. In other cases, it might be relatively easy to guarantee that the loan is used in a way that will prevent its modification under subchapter V. For instance, consider a debtor in a $\$ 500,000$ home with a $\$ 250,000$ purchase-money loan on it, who wishes to borrow (or guarantee) a loan of $\$ 100,000$ for business purposes. Rather than lend only $\$ 100,000$ and take a second lien, the lender should consider taking out the primary lender by lending $\$ 350,000$. That way, more than $70 \%$ of the "new value" was used "in connection with" the home and not the business, and thus should ensure that the creditor's loan cannot be modified so long as it remains secured by the debtor's principal residence.

A similar strategy could be used to extend business loans combined with loans to pay for a debtor's other large expenses, such as their children's cars or educational expenses. Note that even if such amounts are soon paid off-perhaps even before the full loan amount is disbursed - the fact that at the time of lending half of the value was for non-business expenses should arguably protect a lender.

\section{CONCLUSION}

\section{Prediction is very difficult, especially if it's about the future.}

$$
\text { -Unknown. }{ }^{144}
$$

Laws are passed by Congress, but their meanings develop over time. They take shape only gradually. Laws' scope and impact develop from the experience of actual cases and negotiations, informed by the writings and discussions of judges, practitioners, and academics.

It is safe to say that the law of subchapter $\mathrm{V}$ will differ significantly from the rest of chapter 11. In general contours, subchapter $\mathrm{V}$ proceedings seem likely to look much more like chapter 12 or chapter 13 proceedings than typical chapter 11

\footnotetext{
${ }^{143}$ I leave aside the more obvious point that, here, as with respect to other aspects of the Act, creditors may simply decide to restrict credit when their claim to collateral is subject to more uncertainty or when their claim is likely to be dealt with adversely under the Act.

144 One might assume this was uttered by Yogi Berra, but in fact, I have not been able to locate a reliable attribution. It has been attributed to the Nobel Prize-winning scientist, Niels Bohr, as well as a Danish individual named Robert Storm Peterson. See Felicity Pors, Letters to the Editor: the inbox, The perils of prediction, June 2nd, THE ECONOMIST (July 15, 2007), https://www.economist.com/letters-to-the-editor-theinbox/2007/07/15/the-perils-of-prediction-june-2nd (casting doubt on the attribution to both Bohr and Peterson).
} 
cases. That shift is largely one that takes control and leverage away from unsecured creditors, and hands it to the debtor's management and owners. ${ }^{145}$ Courts and trustees can provide some check, of course, but the energy they can or will devote to a particular case is likely to be limited, when no objections have been filed by the parties whose interests are at stake.

My prediction is that the cost of subchapter $\mathrm{V}$ will be borne by general unsecured creditors, at least those without large claims giving them leverage over plan acceptance. With no committee, no need for their acceptance for confirmation, and no control over the identity or activities of the trustee, general unsecured creditors will have significantly less opportunity to keep chapter 11 debtors honest. Debtors are unlikely to be accountable to stakeholders aside from the owners and those whose ongoing cooperation is needed by the owners for the reorganization attempt. Subchapter V is unlikely to dampen the influence of powerful creditors, such as senior secured creditors with large deficiency claims. They will retain significant leverage. Subchapter V will likely redistribute power primarily from the other creditors - junior secured and unsecured creditors - to the debtor. For the main run of creditors, strategic approaches seem likely to provide only limited relief from this generally bleak outlook, in the new small business bankruptcy game of subchapter V.

Copyright 2020 American Bankruptcy Institute. For reprints, contact www.copyright.com.

\footnotetext{
${ }^{145}$ Cf. LOPUCKI \& MiRICK, supra note 5, at 903 ("[I]t will [generally] not be economic for an unsecured creditor to challenge the terms on which the debtor proposes to repay unsecured creditors. Indeed, the general scheme of chapter 13 appears to be to discourage such 'meddling' by the representatives of individual creditors.").
} 